\title{
Heavy metals (Lead and Cadmium) concentration in different organs of mahseer (Tor putitora) of river Indus at Swabi, KPK, Pakistan
}

\author{
Ihtisham-Ur-Rahman ${ }^{1}$, $\operatorname{Irfan}_{\mathrm{Ali}}{ }^{1}$, Ahsan Khan ${ }^{1}$, Waqas Ahmad ${ }^{1}$, \\ Zunaira Safdar ${ }^{1}$, Muhammad Uzair ${ }^{2}$ and Mohsin Khan ${ }^{3}$ \\ 1. Department of Zoology. University of Swabi, KPK-Pakistan \\ 2. Department of Food Sciences. The University of Agriculture Peshawar, KPK-Pakistan \\ 3. Department of Poultry Sciences. The University of Agriculture Peshawar, KPK-Pakistan \\ *Corresponding author's email: Ihtisham.rahaman007@gmail.com
}

Citation

Ihtisham-Ur-Rahman, Irfan Ali, Ahsan Khan, Waqas Ahmad, Zunaira Safdar, Muhammad Uzair and Mohsin Khan. Heavy metals (Lead and Cadmium) concentration in different organs of mahseer (Tor putitora) of river Indus at Swabi, KPK, Pakistan. Pure and Applied Biology. Vol. 9, Issue 4, pp2158-2166. http://dx.doi.org/10.19045/bspab.2020.90230

Received: 00/03/2020 Revised: 00/05/2020

Accepted: 00/06/2020

Online First: 29/06/2020

\section{Abstarct}

The present study was conducted to observed bioaccumulation of heavy metals such as lead and cadmium in gills, swim bladder and muscles tissues of Tor putitora collected from three different locations of River Indus that were Batakra, Ghazi and Kund in District Swabi, Khyber Pakhtunkhwa Pakistan. Present study was conducted from February to April 2016. Fish samples were collected from Batakra in February, from Ghazi in March and from Kund in April. Accumulation of heavy metal in fish sample collected from Batakra in February was in order like Lead $(\mathrm{Pb})(0.03 \mathrm{ppm})>$ Cadmium (Cd) $(0.02 \mathrm{ppm})$ in gills tissue followed by $\mathrm{Pb}(0.02 \mathrm{ppm})>\mathrm{Cd}$ not detected (N.D) in muscle tissue followed by swim bladder tissue having no accumulation of $\mathrm{Pb}$ and $\mathrm{Cd}$. Likewise accumulation of heavy metals in fish sample collected from Ghazi in March was in order like $\mathrm{Pb}(0.02 \mathrm{ppm})>\mathrm{Cd}$ $(0.01 \mathrm{ppm})$ in gills tissue followed by $\mathrm{Pb}(0.02 \mathrm{ppm})>\mathrm{Cd}(\mathrm{N} . \mathrm{D})$ in swim bladder tissue while $\mathrm{Pb}$ and Cd (N.D) in muscle tissues. Similarly accumulation of heavy metals in fish sample collected from Kund in April was in order like $\mathrm{Pb}(0.03 \mathrm{ppm})>\mathrm{Cd}(0.02 \mathrm{ppm})$ in gills tissue followed by $\mathrm{Cd}(0.01 \mathrm{ppm})$ $>\mathrm{Pb}$ (N.D) in swim bladder tissue while $\mathrm{Pb}$ and $\mathrm{Cd}$ (N.D) in muscle tissue. The result indicates that the bioaccumulation of heavy metals definitely affects the aquatic life of freshwater fish mahseer (Tor putitora) and scientific method detoxification is essential to improve the life of these fishes.

Keywords: Bioaccumulation; Heavy metals; Indus; Organs; Tor putitora

\section{Introduction}

The Indus River also called the Sindh River or Abasin. The Indus is the longest and the most important river of Pakistan which ultimately falls into Arabian Sea after distributing its water to some lakes adjacent to its bank like Haleji and Keenjhar lakes [1]. A large portion of our drinking water, just as water utilized for water system, industry and hydropower originate from freshwater lakes and Indus River [2]. Contamination of the Indus River by heavy metals is a significant 
issue in Pakistan. Diverse human activities at the shore of River Indus increase water contamination in Pakistan. The Indus River with $970,000 \mathrm{~km} 2$ seepage bowl zone is one of the world's significant release and dregs load River. It is tainted with modern and local sewage. Rapid industrialization (concrete, cotton ginning and squeezing, manures and flour factories) has additionally expanded the degree of pollution by the arrival of domestic waste items into the River Indus [3]. Lethal heavy metals which are thick metals noted for potential harmfulness in the earth [4]. Heavy Metals are elements with high electrical conductivity, pliability, in addition shine, which intentionally drop their electrons to structure cations. Metals are found normally and their synthesis fluctuate among various areas, bringing about spatial diversities of neighboring focuses. The heavy metal dissemination in the air observed by the possessions of the specified metal and by a number of ecological elements [5]. Substantial metals are for the most element alluded to as the ones metals which have a particular thickness of in excess of $5 \mathrm{~g} / \mathrm{cm}^{3}$ and unfavorably have an impact on nature and living biota [6]. These metals are essential to maintain up unique bio-synthetic and physiological capacities in living organisms when in low amount; anyway they become toxic when they surpass their thresh hold level affecting the cellular functions of organisms. Despite the point that it is documented those essential metals have several unfavorable health impacts and keep going for long time and is passing in numerous life forms of the biosphere through food chain. Heavy metals are natural toxic substance and their lethality is an problematic of growing significance for living, transformative, nutritious and ecological causes [7]. The furthermost universally discovered heavy metals in sanitation water combine arsenic, cadmium, chromium, copper, lead, nickel and zinc. All of these heavy metals are harmful for human being as well as for the aquatic biota exposed to these heavy metals [8]. Heavy metals come into the environments by ordinary methods and over activities of human. Different sources of heavy metals involves soil degeneration, common enduring of the world's outside layer, mining, mechanical wastes, urban excess, manure discharge, bug or malady control operators applied to yields and several others [9]. Lead is an exceptionally harmful metal which excess utilize has caused broad ecological sullying and medical issues in numerous biotics of the biosphere. Lead is a brilliant shimmering metal, marginally somewhat blue in a dry environment. It starts to discolor on contact with air, in this manner framing a mind boggling blend of mixes, contingent upon the wellsprings of lead presentation incorporate mostly modern procedures, nourishment and smoldering, ingesting water and native bases. The wellsprings of $\mathrm{Pb}$ were gas, household paint, which has been reached out to lead projectiles, sanitation funnels and pewter pitchers, stockpiling batteries, models and spigots [10]. Other than 100 to 200,000 tons of $\mathrm{Pb}$ in the US for every year is being discharged from automobile debilitates. Certain metals are used by plants, obsession to soil and stream into aquatic bodies, subsequently anthropological presentation of $\mathrm{Pb}$ in the all-inclusive community is moreover because of nourishment or drinking water [11]. Pb is an amazingly harmful heavy metal that upsets different plant biological procedures and not at all like different metals, for example, zinc, copper and manganese, it doesn't play any bio-consistent vital role. A plant with high lead focus secures the generation of receptive oxygen species (ROS) causing lipid leyar harmness that at last prompts harm of chlorophyll and also the photosynthesis process as well as effects the general development of the plant [12]. Various explorations uncovered that $\mathrm{Pb}$ is fit 
for repressing development of tea shrub by decreasing biomasses and degrade the plant value by fluctuating the nature of its parts [13]. Indeed, even at lesser fixations, $\mathrm{Pb}$ treatment was initiate to cause colossal insecurity in particle take-up via plants, which thusly prompts huge metabolic fluctuations in photosynthetic limit and at last in a solid restraint of plant development [14]. In the earth cadmium normally present in soil, air, residue and unpolluted seawater. Cadmium is transmitted to air by mines, enterprises utilizing cadmium mixes for compound, batteries and metal smelter, shades and in plastics [15]. Tobacco smoke is one of the main source of cadmium introduction in human. In view of the retention of cadmium from lungs a lot more noteworthy than from the gastrointestinal tract, smoking contributes fundamentally to the absolute body problems [16]. Cadmium can harm cellular activities and kidney role in fish [17]. Cadmium likewise harms a few organs in human body liver, lungs, bones and focal sensory system [18]. From Tibetan level western China Indus waterway emerging ventures northwest through the Himalayan valleys and in the wake of intersection into the Kashmir area and navigating Pakistan, streams out into the Arabian Sea [19]. In Pakistan just waterway Indus is the single significant water asset, depending vigorously occasional downpour fall and frigid soften for its normal fall, the Indus bowl framework is the foundation of agrarian economy of Pakistan with seepage region is $56 \%$ [20]. Tor pitutora has nutritive and commercial as well as economic value; therefore, the present study was conducted to represent some scientific information about the bioaccumulation of lead and cadmium in different organ (such as gills, swim bladder and muscle) of Tor pitutora.

\section{Materials and methods}

During collection of fishes and the research carried out in laboratory following materials were used. Hooks, hand nets, surgical blades, petri dish, counting needles, forceps, electronic weighting balance, beakers, conical flask, micro oven, desiccators, hot plates, fuming hood machine, masks, gloves and for digestion of samples 3:1 solution of $\mathrm{HClO}_{4}$ (Hydrogen per chloric acid) and $\mathrm{H}_{2} \mathrm{SO}_{4}$ (Sulphuric acid) $15 \mathrm{ml}$ for each 1 gram tissue sample. Atomic Absorption Spectroscopy (AAS) machine were used for metal detection inside P.C.S.I.R laboratory.

\section{Fish collection and fish labeling}

In February, March and April, the fish were collected from Batakra, Ghazi and Kund respectively. The fish were collected by using hooks, meshed cast nets and fishing rods. After collection, the fish were identified with help of key and were preserved in icebox for further laboratory analysis. The icebox was labeled with weight, length, date, time, location and local name of fish at site of collection.

\section{Laboratory work procedure}

After collection, labeling and identification the fish samples were brought to Pakistan Council \& Scientific Research (PCSIR) laboratory Peshawar for fish dissection, sample preparation and heavy metal analysis. For the removal of ice the fish samples were kept open for fifteen minutes. Firstly, the beakers were thoroughly washed with distal water to remove any impurities if present. Beakers were kept in micro-oven for 5 minutes to dry. Then the beakers were kept in desiccators to prevent any contamination from surrounding. Sample from each organ (gill, swim bladder and muscles) were taken respectively into separate beaker for wet digestion. All the samples were weighted through digital weight balance and sample weight were recorded. $\mathrm{HClO}_{4}(\mathrm{Hydrogen}$ per chloric acid) and $\mathrm{H}_{2} \mathrm{SO}_{4}$ (Sulphuric acid) with 3:1 were added into beaker and shacked gently. The beaker were placed on the hot plate for digestion at $200{ }^{\circ} \mathrm{C}$ in fume hood. The beaker was covered with watched glass 
to prevent sample contamination from the fume hood environment. The volume of the sample reduced to about $20 \mathrm{ml}$ with heating at $200{ }^{\circ} \mathrm{C}$ for 2.5 hours approximately until the white fume of $\mathrm{H}_{2} \mathrm{SO}_{4}$ (sulphuric acid) appears leaving a clear creamy solution. To prevent the solution from drying distal water were added when needed. I put a spare beaker containing $20 \mathrm{ml}$ of water for using as a gauge. After hot palate, the lip of beaker was covered with watch glass to reduce any additional evaporation and gently refluxed the sample for $30 \mathrm{~min}$. After digestion and cooling, the water samples were filtered through filter paper (Whatsman No.42) in a 25-ml volumetric flask if contain any suspended particles. Distilled water were added to make the solution $25 \mathrm{ml}$, if needed. The water samples were ready for heavy metals analysis ( $\mathrm{Pb}$ and $\mathrm{Cd}$ ) and were determined with an atomic absorption spectrophotometer (Spectra-AA-700). During analysis standard conditions were set to detect heavy metals in water samples. A range of analytical standard for each metal was prepared from E. Merck stock solution. Standard curves were prepared and the ODs (optical densities) obtained were calibrated against the standard curves to know the concentration of heavy metal in tissue samples (Table 1).

Table 1. Analyzing the heavy metals variables through atomic absorption spectrophotometer (Spectra-AA-7)

\begin{tabular}{|c|c|c|c|c|c|}
\hline S. No. & Elements & $\begin{array}{c}\text { Wavelength } \\
(\mathbf{n m})\end{array}$ & $\begin{array}{c}\text { Flame gases } \\
\text { (A-AC air acetylene) }\end{array}$ & $\begin{array}{c}\text { Lamp current } \\
\text { (m-ampere) }\end{array}$ & $\begin{array}{c}\text { Band } \\
\text { pass }\end{array}$ \\
\hline 1 & Cadmium $(\mathrm{Cd})$ & 112.4 & A-AC & 10 & 0.5 \\
\hline 2 & Lead $(\mathrm{Pb})$ & 283.3 & A-AC & 10 & 0.5 \\
\hline
\end{tabular}

\section{Results}

\section{Comparative result of Lead concentration}

Absorption of lead in gill tissue for the month of February, March and April was 0.03, 0.20 and 0.22 ppm respectively with Mean \pm S.D $=$ $0.14 \pm 0.11$ as shown in (Table 2; Fig. 1). Similarly, concentration of lead in swim bladder tissues for the month of February,
March and April were N.D, 0.02 and 0.01 ppm respectively with Mean \pm S.D $=0.01 \pm$ 0.00 as shown in (Table 2; Fig. 1). Lead concentration in muscle tissues for the month of February, March and April were 0.02, 0.01 and N.D respectively with Mean \pm S.D $=0.01$ \pm 0.00 as shown in (Table 2; Fig. 1).

Table 2. Showing comparative result of lead concentration observed in February, March and April

\begin{tabular}{|c|c|c|c|c|c|c|}
\hline S. No. & Organ & Weight & February & March & April & Mean \pm S.D \\
\hline 1 & Gill & $1 \mathrm{gm}$ & 0.03 & 0.20 & 0.22 & $0.14 \pm 0.11$ \\
\hline 2 & Swim bladder & $1 \mathrm{gm}$ & N.D & 0.02 & 0.01 & $0.01 \pm 0.00$ \\
\hline 3 & Muscle & $1 \mathrm{gm}$ & 0.02 & 0.01 & N.D & $0.01 \pm 0.00$ \\
\hline
\end{tabular}

\section{Comparative result of Cadmium concentration}

Concentration of cadmium in gill tissues for the month of February, March and April were $0.03,0.01$ and $0.22 \mathrm{ppm}$ respectively with Mean \pm S.D $=0.18 \pm 0.11$ as shown in (Table 3; Fig. 2). Similarly concentration of cadmium in swim bladder tissues for the month of February, March and April was N.D, N.D and $0.01 \mathrm{ppm}$ respectively with Mean \pm S.D $=0.01 \pm \mathrm{NaN}$ as shown in (Table 3; Fig. 2). Cadmium concentration in muscle tissues for the month of February, March and 
April was $0.02,0.02$ and N.D respectively with Mean \pm S.D $=0.02 \pm 0.0$ as shown in

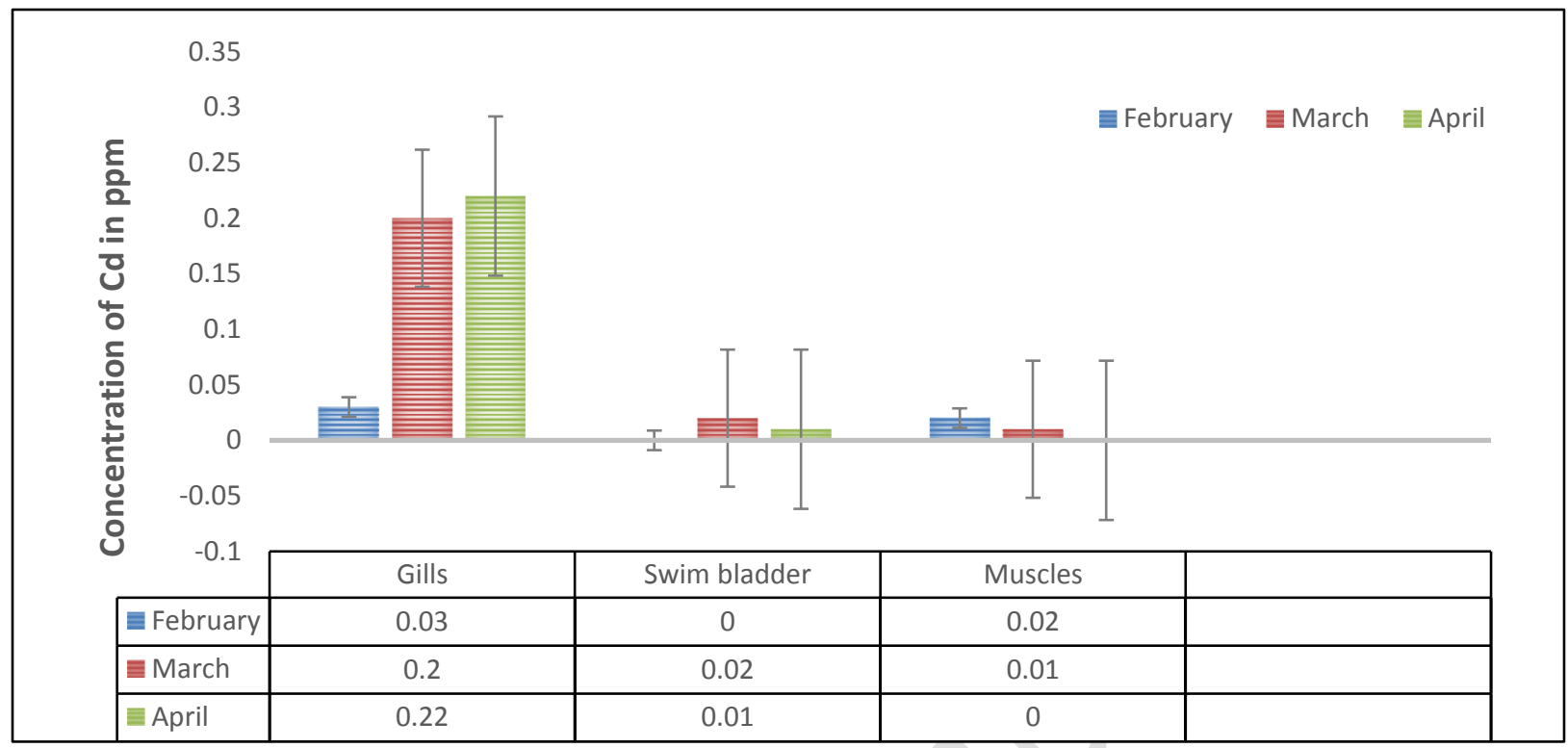

(Table 3; Fig. 2).

Figure 1. Showing comparative result of cadmium concentration observed in February, March and April

Table 3. Showing comparative result of lead concentration observed in February, March and April

\begin{tabular}{|c|c|c|c|c|c|c|}
\hline S. No. & Organ & Weight & February & March & April & Mean \pm S.D \\
\hline 1 & Gill & $1 \mathrm{gm}$ & 0.03 & 0.01 & 0.22 & $0.18 \pm 0.11$ \\
\hline 2 & Swim bladder & $1 \mathrm{gm}$ & N.D & N.D & 0.01 & $0.01 \pm$ NaN \\
\hline 3 & Muscle & $1 \mathrm{gm}$ & 0.02 & 0.02 & N.D & $0.02 \pm 0.0$ \\
\hline
\end{tabular}

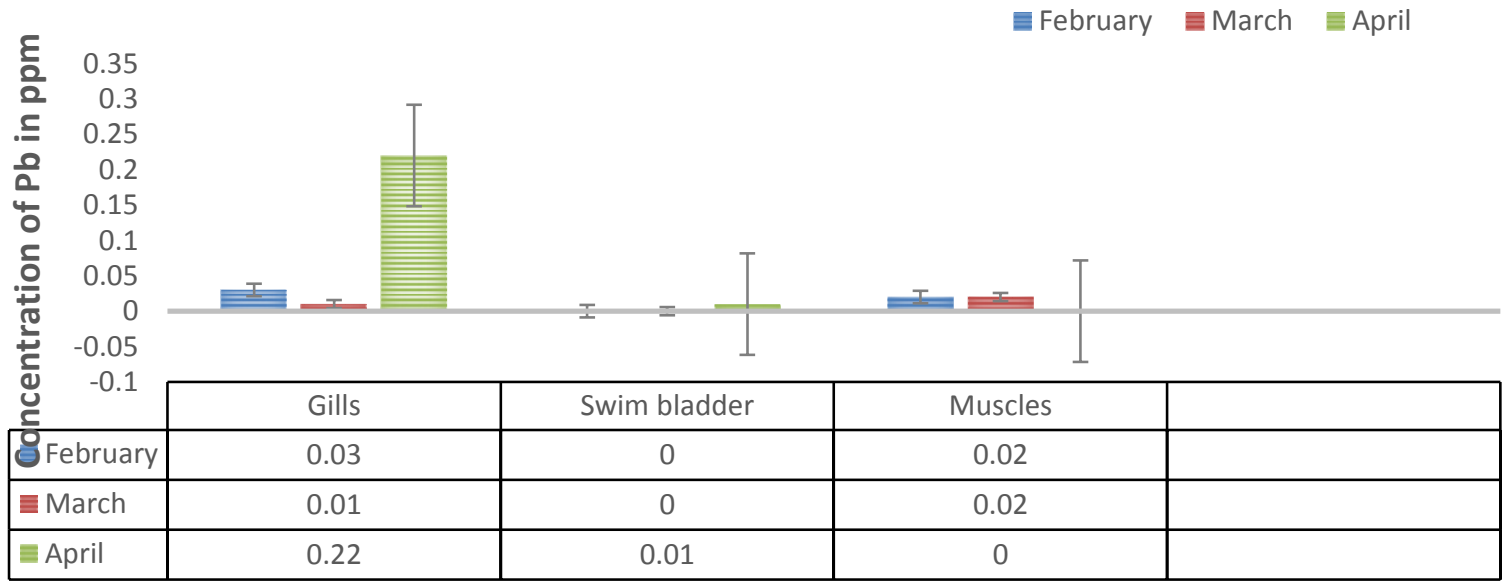

Figure 2. Showing comparative result of cadmium concentration observed in February, March and April 


\section{Discussion}

Since a long time, fishes had been consumed by people and animals as a primary source of protein as a meal. Fishes comprise all those nutrients in their organs which are necessary for our growth. Due to the presence of diverse minerals and vitamins, fishes are an outstanding nutritional supplier [20]. The present study was carried out in three different location of Indus River that was Batakra, Ghazi and Kund in the month of February, March and April respectively. The current study revealed that concentration of heavy metal in fish samples collected from Batakra in February was in order like pb $(0.03 \mathrm{ppm})>\mathrm{cd}(0.02 \mathrm{ppm})$ in gills tissue followed by $\mathrm{pb}(0.02 \mathrm{ppm})>\mathrm{cd}$ (N.D) in muscle tissues and pb and cd (N.D) in swim bladder tissues because untreated water is added from gadoon amanzai industries which pollute the Indus river water which is hazardous for fishes and other animals as well as human being exposed to it. According to [21] found lead in the gills and muscle tissue. The reasons for increased lead concentration were found to be the anthropogenic activities (boat repairing, painting), presence of automobile workshop on the banks of the lake, and lead-bearing minerals present in the catchment rock creation. The observed concentration of Lead in the lake water was above the permissible limit of the metal as per guidelines issued by central pollution control board (CPCB) (0.1 mg. $\left.\mathrm{L}^{-1}\right)$ for the inland surface water and world health organization W.H.O (0.05 ppm) for the drinking water. Lead enters the aquatic surroundings through erosion and leaching from the lead dust fallout, burning of gas, and municipal and industrialized discharges. Lead is a leading purpose of beginning defects, cardiovascular disease, high blood pressure, neurological disease, kidney disorder, learning disability, retardation, enamel cavities and so forth in humans [22]. It has been found that cadmium (0.02ppm) in gills according [21] during his investigation period, concentration of Cadmium varied from 0.00 to $0.01 \mathrm{ppm}$. The possible reasons for the increased concentration of Cadmium include erosion of natural deposits, discharge of municipal wastes, corrosion of galvanized pipes, washings of dyes, paints of boats etc. According to Khan et al. found (0.05 ppm) lead and cadmium in water at batakara near gadoon amazai. Cadmium is considered as a poisonous metal and is perilous to both human and untamed life. It goes about as a mutagens and enhances malignant growth in various tissues. It likewise animates cell multiplication, restrain DNA repairing and hinder apoptosis. From one viewpoint it prompts the cell demise which prompts tissue harm in kidney. In cell culture frameworks, cadmium at low fixation cause apoptosis and with increment in focus putrefaction become apparent. Cadmium likewise influences the renal capacity when presented to nature [23]. Likewise accumulation of heavy metals in fish sample collected from Ghazi in March was in order like pb $(0.02 \mathrm{ppm})>\mathrm{cd}$ $(0.01 \mathrm{ppm})$ in gills tissue followed by $\mathrm{pb}$ $(0.02 \mathrm{ppm})>\mathrm{cd}$ (N.D) in swim bladder tissue and $\mathrm{pb}$ and $\mathrm{cd}$ (N.D) in muscle tissues. $\mathrm{Pb}$ and $\mathrm{Cd}$ were accumulated frequently in the gills. The accumulation example of $\mathrm{Pb}$ and $\mathrm{Cd}$ varied between species where the centralization of metals changed among the gills and liver [21]. The accumulation of fundamental and follow metals in the liver is identified with the capacity in digestion [24]. According to [25] found lead higher concentration in gills followed by other tissue. $\mathrm{Pb}$ impacts everyday growth and causes intellectual retardation in children. In adults it reasons hypertension and cardiac diseases. [26] According to cadmium were detected in gills but not detected in other tissues. The poisonousness of $\mathrm{Pb}$ and $\mathrm{Cd}$ is well recognized [27]. $\mathrm{Cd}$ is not taken as necessary element for humans and regarded 
to be a detail dangerous for the organs such as liver, lungs and kidneys [28]. It is understood that $\mathrm{Cd}$ accumulates in both kidneys and liver. Half-life of this heavy metal in human frame is between 10-14 years [29]. Cadmium exposures may lead to genomic instability and tumor genesis by inhibiting DNA repairs at various levels [30]. Urinary cadmium has various effects on other tissues such as lungs, periodontal tissues, hypertension, diabetes and mammary glands. There is a reduction of forced expiration (reflection of lung function) with increased urinary cadmium in smoking individuals [31]. Similarly accumulation of heavy metals in fish sample collected from in April was in order like $\mathrm{pb}(0.03 \mathrm{ppm})>\mathrm{cd}(0.02 \mathrm{ppm})$ Kund in gills tissues followed by cd $(0.01 \mathrm{ppm})>\mathrm{pb}$ (N.D) in swim bladder tissues and $\mathrm{pb}$ and cd (N.D) in muscle tissues. According to pradip et al. found lead $(0.057 \mathrm{ppm})$ in gills where muscle show lower concentration. He found cadmium in gills as less amount whereas no cadmium were found in other tissue. According to [32] found 0.02 $\mathrm{mg} / \mathrm{l}$ in water near kund at river Indus. Heavy metals harmfully disturbed the growing rate in major carp. Fish are frequently at the top of aquatic food chain and may concentrate large amounts of certain metals from the water. Various factors including season, physical and chemical properties of water can play an important role in metals accumulation in different fish tissues. The gills are directly in contact with water. Therefore the concentration of metals in gills reflect their concentration in water where the fish live whereas the concentration in liver represent storage of metals in the water [33]. Lead is an particularly toxic heavy metal that disrupts various plant biological processes, and unlike other metals, such as zinc, copper, and manganese, it does not play any biological functions [34]. Cadmium exposure may occur at lower exposure levels than previously anticipated, primarily in the form of kidney damage but possibly also bone effects and fractures [35]. Our study revealed that, maximum accumulation of $\mathrm{pb}$ and $\mathrm{cd}$ was in gills tissue in fish samples collected from each site. $\mathrm{Pb}$ has also shown maximum accumulation in gills as compared to cd and likewise pb was also found to be accumulated in muscle tissue as compared to cd. So it was concluded that lead shows maximum accumulation in all tissues and it may be due to maximum concentration of lead in all their three sites. As the quantity of lead observed is still did not reached to toxic level but if contamination of lead were continued from the external environment in the water with this pace may harm the aquatic fauna as well as the human being via food chain.

\section{Conclusion}

The present study deals with identification of heavy metals lead and cadmium in different tissues of Mahseer collected from three different locations that were Batakra, Ghazi and Kund of River Indus. Present study were conducted for three months and lead and cadmium were reported in gills, swim bladder and muscles of maer. In present study it was reported that maximum accumulation of heavy metals were observed in gills as compared to swim bladder and muscles. The present study reported that heavy metals are present in gills of all mahseer collected from different sites of River Indus in different months while in swim bladder and muscles lead and cadmium were not detected or detection were below permissible limits. Our study revealed that maximum accumulation of $\mathrm{Pb}$ and $\mathrm{Cd}$ were in gills tissue in fish samples collected from each site. $\mathrm{Pb}$ has also shown maximum accumulation in swim bladder as compared to $\mathrm{Cd}$ and likewise $\mathrm{Pb}$ was also found to be accumulated in muscle tissue as compared to $\mathrm{Cd}$. So it was concluded that lead shows maximum accumulation in all tissues and it may be due to maximum concentration of lead in all three sites. As the quantity of lead observed is still 
did not reached to toxic level, but if so in adding of lead is continued from the external environment it can harm the aquatic fauna as well as the human being via food chain. So to reduce solubility of such heavy metals we must quantifying the river water with time to time by following necessary measures.

\section{Authors' contributions}

Conceived and designed the experiments: IU Rahman, I Ali, A Khan \& W Ahmad, Performed the experiments: IU Rahman, I Ali, W Ahmad, M Khan \& M Uzair, Analyzed the data: I Ali, M Khan, Z Safdar \& A Khan, Contributed reagents/ materials/ analysis tools: I Ali, IU Rahman, Z Safdar, M Khan, W Ahmad \& M Uzair, Wrote the paper: IU Rahman \& I Ali.

\section{References}

1. Rengarajan S, Palaniyappan D, Ramachandran $\mathrm{P}$ \& Ramachandran $\mathrm{R}$ (2018). National Green Tribunal of India an observation from environmental judgements. Environ Sci and Pollut Res Inter 25(12): 11313-11318.

2. Anon R (1992). Standard methods of water and wastewater examination. Americ Pub Health Asso Washing DC 2-172.

3. Jabeen S, Shah MT, Khan S \& Hayat MQ (2010). Determination of major and trace elements in ten important folk therapeutic plants of Haripur basin, Pakistan. $J$ of Med Plants Res 4(7): 559-566.

4. Srivastava GP, Qiu J \& Xu D (2010). Genome-wide functional annotation by integrating multiple microarray datasets using meta-analysis. Inter J of Data Mining and Bioinforma 4(4): 357-376.

5. Khlifi R \& Hamza CA (2010). Head and neck cancer due to heavy metal exposure via tobacco smoking and professional exposure: a review. Toxicol and Appl Pharma 248(2): 71-88.

6. Järup L (2003). Hazards of heavy metal contamination. British Med Bullet 68(1): 167-182.

7. Jaishankar M, Tseten $\mathrm{T}$, Anbalagan N, Mathew BB \& Beeregowda KN (2014). Toxicity, mechanism and health effects of some heavy metals. Interdiscip Toxicol 7(2): 60-72.

8. Lambert DM \& Cooper MC (2000). Issues in supply chain management. Indust Market Managt 29(1): 65-83.

9. Morais S, Costa FG \& Pereira MDL (2012). Heavy metals and human health. Environ Health-Emerging Iss and Pract 10: 227246.

10. Thürmer K, Williams E \& Reutt-Robey J (2002). Autocatalytic oxidation of lead crystallite surfaces. Sci 297(5589): 20332035.

11. Goyer RA (1990) taxological metals Transplacental Transfer of Lead and Cadmium 10.1007/978-3-642-79162-8_1

12. Najeeb U, Ahmad W, Zia MH, Zaffar M \& Zhou W (2017). Enhancing the lead phytostabilization in wetland plant Juncus effusus L. through somaclonal manipulation and EDTA enrichment. Arab J of Chem 10: S3310-S3317.

13. Yongsheng W, Qihui L \& Qian T (2011). Effect of $\mathrm{Pb}$ on growth, accumulation and quality component of tea plant. Procedia Engi 18: 214-219.

14. Mostafa M, Hossain H, Hossain MA, Biswas PK \& Haque MZ (2012). Insecticidal activity of plant extracts against Tribolium castaneum Herbst. $J$ of Advanced Sci Res 3(3).

15. Kalay M, Ay O \& Canli M (1999). Heavy metal concentrations in fish tissues from the Northeast Mediterranean Sea. Bull of Environ Contami and Toxicol 63(5): 673681.

16. Ukabiala CO, Nwinyi O, Abayomi A \& Alo BI (2010). Assessment of heavy metals in urban highway runoff from Ikorodu expressway Lagos, Nigeria. $J$ of Environ Chem and Ecotoxicol 2(3): 34-37.

17. Figueroa FL, Israel A, Neori A, Martínez B, Malta EJ, AngJr P \& Korbee N (2009). Effects of nutrient supply on photosynthesis and pigmentation in Ulva lactuca (Chlorophyta): responses to short-term stress. Aquatic Biol 7(1-2): 173-183.

18. Mansour MA, Nagi MN, El-Khatib AS \& Al-Bekairi AM (2002). Effects of thymoquinone on antioxidant enzyme activities, lipid peroxidation and DT- 
diaphorase in different tissues of mice: a possible mechanism of action. Cell Biochem and Func 20(2): 143-151.

19. Gonzalez MC, Hidalgo CA \& Barabasi AL (2008). Understanding individual human mobility patterns. Nature 453(7196): 779.

20. Fındık Ö \& Çiçek E (2011). Metal concentrations in two bioindicator fish species, Merlangius merlangus, Mullus barbatus, captured from the West Black Sea Coasts (Bartin) of Turkey. Bullet of Environ Contam and Toxicol 87(4): 399.

21. Joshi PK, Mishra A \& Sharma AP (2018). Assessment of bio-accumulation of heavy metals in Tor putitora from Lake Nainital, Uttarakhand. J of Entom and Zool Stud 6(3): 448-453

22. Mason RP, Fitzgerald WF \& Morel FM (1994). The biogeochemical cycling of elemental mercury: anthropogenic influences. Geochimica et Cosmochimica Acta 58(15): 3191-3198.

23. Templeton DM \& Liu Y (2010). Multiple roles of cadmium in cell death and survival. Chemico-Biol Interac 188(2): 267-275.

24. Zhao S, Feng C, Quan W, Chen X, Niu J \& Shen Z (2012). Role of living environments in the accumulation characteristics of heavy metals in fishes and crabs in the Yangtze River Estuary, China. Marine Pollut Bull 64(6): 1163-1171.

25. Khan MS, Khan S, Khan I, Aminurrahman \& Iqbal Y (2002). Multielemental studies of polluted water of Peshawar valley (NWFP) Pakistan. J of the Chemic Soci of Pak 24(3): 159-170.

26. Verougstraete V, Lison D \& Hotz P (2003). Cadmium, lung and prostate cancer: a systematic review of recent epidemiological data. $J$ of Toxicol and Environ Health, Part B 6(3): 227-256.

27. Dessuy MB, Vale MGR, Welz B, Borges AR, Silva MM \& Martelli PB (2011). Determination of cadmium and lead in beverages after leaching from pewter cups using graphite furnace atomic absorption spectrometry. Talanta 85(1): 681-686.

28. Rezende HC, Nascentes CC \& Coelho NM (2011). Cloud point extraction for determination of cadmium in soft drinks by thermospray flame furnace atomic absorption spectrometry. Microchem $J$ 97(2): 118-121.

29. Méndez JÁ, García JB, Crecente, RMP, Martín SG \& Latorre CH (2011). A new flow injection preconcentration method based on multiwalled carbon nanotubes for the ETA-AAS determination of $\mathrm{Cd}$ in urine. Talanta 85(5): 2361-2367.

30. Waisberg M, Joseph P, Hale B \& Beyersmann D (2003). Molecular and cellular mechanisms of cadmium carcinogenesis. Toxicol 192(2-3): 95-117.

31. Lampe BJ, Park SK, Robins T, Mukherjee $\mathrm{B}$, Litonjua AA, Amarasiriwardena $\mathrm{C} \& \mathrm{Hu}$ H (2008). Association between 24-hour urinary cadmium and pulmonary function among community-exposed men: the VA Normative Aging Study. Environ Health Perspec 116(9): 1226-1230.

32. Khan A, Yousafzai AM, Latif M, Rehman A, Khan Q, Zaib A \& Aziz A (2014). Analysis of selected water quality parameters and heavy metals of Indus River at BekaSwabi, Khyber Pakhtunkhwa, Pakistan. Internat J of Biosci (IJB) 4(2): 2838.

33. Abdul R, Muhammad J, Muhammad U \& Sajid A (2009). Assessment of heavy metals in sediments of the river Ravi, Pakistan. Inter J of Agric and Biol 11(2): 197-200.

34. Jaishankar $\mathrm{M}$, Tseten $\mathrm{T}$, Anbalagan $\mathrm{N}$, Mathew BB \& Beeregowda KN (2014). Toxicity, mechanism and health effects of some heavy metals. Interdis Toxicol 7(2): 60-72.

35. Järup L (2003). Hazards of heavy metal contamination. British Med Bull 68(1): 167182. 